\title{
BIO CONCRETE AND BACTERIA BASED SELF HEALING CONCRETE
}

\author{
Harshali J. ${ }^{1}$, Mitali S. ${ }^{2}$, Neha A. ${ }^{3}$, Pragati B. ${ }^{4}$ \\ ${ }^{1}$ Harshali A. JadhavB. E. Student, Department of Civil Engineering, Gokhale Education Society's R. H. Sapat \\ College of Engineering, Nashik - 422005, Maharashtra, India. \\ ${ }^{2}$ Mitali P. Shelke B. E. Student, Department of Civil Engineering, Gokhale Education Society's R. H. Sapat College of \\ Engineering, Nashik - 422005, Maharashtra, India. \\ ${ }^{3}$ Neha U. Anwekar B. E. Student, Department of Civil Engineering, Gokhale Education Society's R. H. Sapat College \\ of Engineering, Nashik - 422005, Maharashtra, India. \\ ${ }^{4}$ Pragati Bohare B. E. Student, Department of Civil Engineering, Gokhale Education Society's R. H. Sapat College of \\ Engineering, Nashik - 422005, Maharashtra, India.
}

\begin{abstract}
Concrete is cheap and easily available construction material in the world. So advancement in the concrete is to improve its compressive strength and durability of structures by using micro organisms carrying process of MICP. This project discusses the filling of voids in fresh concrete and plugging of artificially cracked cement mortar using Bacillus Sphaericus and Proteus Vulgarious bacteria combined with sand as a filling material in artificially made cuts in cement mortar which was cured in urea and $\mathrm{CaCl}_{2}$ medium. The effect on the compressive strength, flexural strength due to the mixing of bacteria along with effect of water absorption and sorptivity on concrete cubes is also discussed in this project. The main aim of the project is to evaluate the strength in comparison with conventional and bio concrete cubes. The evaluated results suggest that there is significant increase in the strength of concrete
\end{abstract}

Keywords: Microbiologically Induced Calcite Precipitation, Whitish Yellow Turbid Solution

\section{INTRODUCTION}

Bio concrete is the science of precipitation of minerals by living organisms. Bacteria have a remarkable ability to precipitate Calcite, Carbonate, Phosphate, Oxides, sulphite. In bio concrete Bacterial species like, B. Sphaericus Proteus Vulgarious, etc,.deposit calcium carbonate by their bacterial activity in this system. This result decreases in water absorption and permeability. Presence of layer of Calcium precipitation improves its strength and durability.

Cracking is a common phenomenon in concrete due to the relatively low tensile strength. Without immediate and proper treatment, cracks tend to expand further and eventually require costly repair. Inducing bacteria along with precursor compound heals crack by calcite precipitation which compressive strength and durability of structure.

\section{METHODOLGY}

Combination of two bacterias will give good results as compared to one bacteria. Hence we came up with two bacteris which are totally harmless Bacillus Spericus and Protius Vulgarius.

\subsection{Preparation of Bacterial solution}

Primarily 12.5 grms of nutrient growth added to $500 \mathrm{ML}$ conical flask containing distilled water. Then it is covered with thick cotton plug and is made air tight with paper and rubber band. Then it is sterelized using a cooker for $10-20$ Min. Now solution is free from contamination and solution is clear orange in colour before the addition of bacteria. Later flask is open up and $1 \mathrm{ML}$ of bacterium is added to sterelized flask and kept in shaker at speed of $150-200 \mathrm{rpm}$ overnight. After $24 \mathrm{hrs}$ bacterial solution was found to be Whitish Yellow Turbid solution.
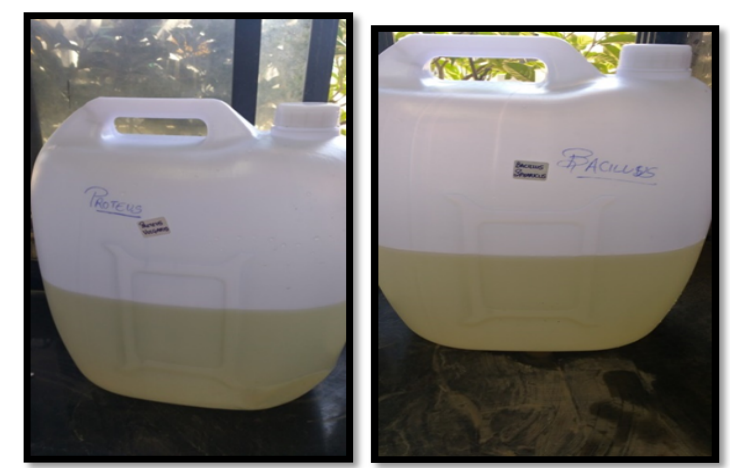

Fig. 1 : Whitish yellow turbid bacterial solution

\subsection{Bacterial Growth Curve}

1. It is an experiment to determine the growth curve of the bacillus spericus and proteus vulgarious carried out using shake flask culture technique to set a growth of bacteria. 
2. A colony of an overnight cuture used to inoculate $30 \mathrm{ml}$ of media ( nutrient broth ) in a $250 \mathrm{ml}$ conical flask.

3. The culture incubeted at $37^{\circ} \mathrm{C}$ by shaking for $24 \mathrm{hrs}$ at $120 \mathrm{rpm}$.

4. The sample is taken from the culture at $3 \mathrm{hrs}$ time interval which measures O.D. (optical density) colorimertically at $530 \mathrm{~nm}$

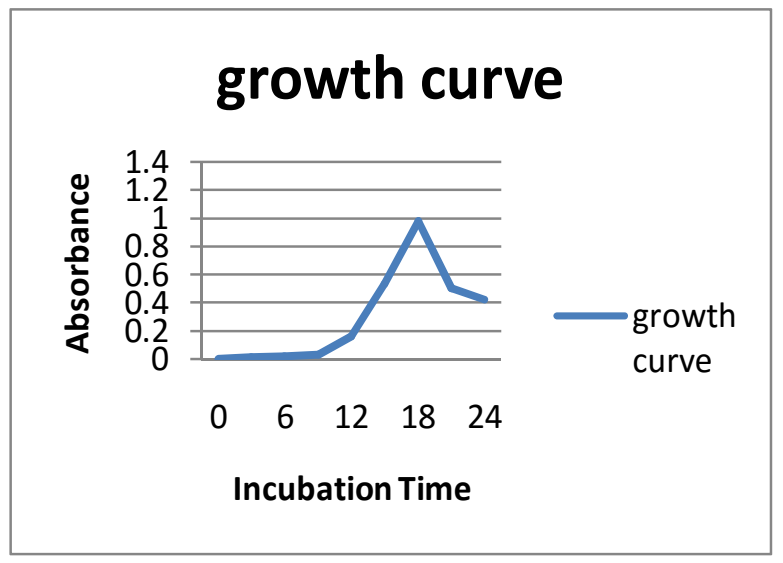

Graph 1. Graph Growth Curve of Proteous Vulgarious

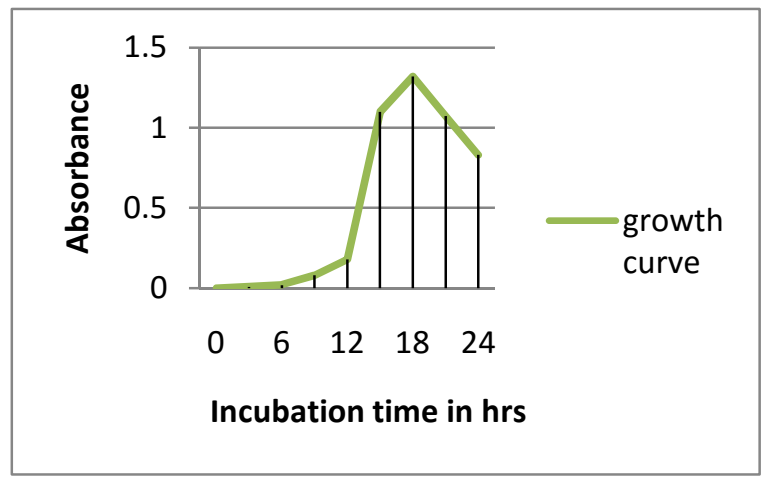

Graph 2. Graph Growth Curve of Bacillus Sphaericus

\subsection{Precipitation Test On Bacteria}

Estimation of calcite precipitation by EDTA titration -

The sample is first adjusted to $\mathrm{pH}$ of 10 using sodium hydroxide buffer solution. A few drops of Eriochome Black ( $0.5 \% \mathrm{wt} / \mathrm{vol}$.) indicator was added and sample was titrated against $0.01 \mathrm{M}$ of sodium ethylene diamine tetra acetate (EDTA). EDTA draws the calcium and magnesium ions into complex, so neither one has free ions in solutions. The indicator initially turns red in presence of calcium and magnesium and then it turns to metallic blue when enough EDTA solution has been added to combine with all calcium and magnesium. The total precipitation of bacterial sample (consortia of bacillus sphaericus, proteus vulgaris) is calculated using the precise volume of EDTAsolution added when indicator changes colour. The calcium carbonate concentration was calculated according to following equation:

$\mathrm{Ca}_{2} \mathrm{Co}_{3}(\mathrm{Mg} / \mathrm{l})=[\mathrm{Vol}$ EDTA $(\mathrm{ml}) /$ sample volume $(\mathrm{L}) \times\left[\mathrm{Ca}_{2} \mathrm{CO}_{3}(\mathrm{ml}) / \mathrm{EDTA}(\mathrm{mol})\right]$

\section{Result of the Test}

Change in colour from wine red to steel blue by reducing EDTA

Total hardness $10 \mathrm{ml}$ of bacteria solution $(5 \mathrm{ml}$ of bacillus sphaericus culture $+5 \mathrm{ml}$ proteus vulgarius culture) $+2 \%$ of urea $+25 \mathrm{Mm} \mathrm{CaCl} 2=1.125 \mathrm{mg} / \mathrm{lit}$

\subsection{Casting of Bio Concrete Cubes (15) and Cuboids (3)}

We casted batch of M25 grade concrete on $2^{\text {nd }}$ February 2016. In this batch of bio concrete we used the mixture of Cement, Sand, Artificial Aggregate and Bacterial solution. There was no use of water and admixtures. After casting all moulds were placed in room tempeature for period of 24 hours. After 24 hours these moulds were removed and the test specimen of bio concrete were put for curing on $3^{\text {rd }} \mathrm{Feb}$, in the bacteial solution including its precursor compound as calcium chloride and urea in a separate tank.

Accordingly the 3rd, 7th and 28th day compression tests were conducted. The 28th day flexure, Water absorption and sorptivity tests are performed on $1^{\text {st }}$ March 2016.

Then the graph for Compressive strength verse No. of days and one more graph for Flexural strength verses No of days is ploted.The results betweeen conventional concrete and bio concrete is compared.

Similarly the conventional cubes are casted, by replacing bacterial solution with water.

\subsection{Tests On Conceret Cubes}

1. Compressive Strength test.

2. Flexural Strength Test.

3. Water absorption test.

4. Sorptivity test

The compressive, flexure and water absorption tests are performes as per IS... and the sorptivity test is as follows :

\section{Sorptivity Test}

Sorptivity gives capillary action of water. For sorptivity test $150 \mathrm{~mm} \times 150 \mathrm{~mm} \times 150 \mathrm{~mm} 6$ cubes $(3$ conventional, 3 bio concrete) was casted. After 28 days continuous curing the specimen was oven dried for 24 hours and cooled at room temperature. Then we coated the cubes with Dr fixit from 4 sides. The base portion was kept open. We weightedthis cube as $\left(\mathrm{W}_{1}\right)$. Again the specimen was kept in water where the height of specimen immersed only $5 \mathrm{~mm}$ for 60 minutes. After $60 \mathrm{~min}$ the weight of specimen measured in $\mathrm{gm}\left(\mathrm{W}_{2}\right)$. 

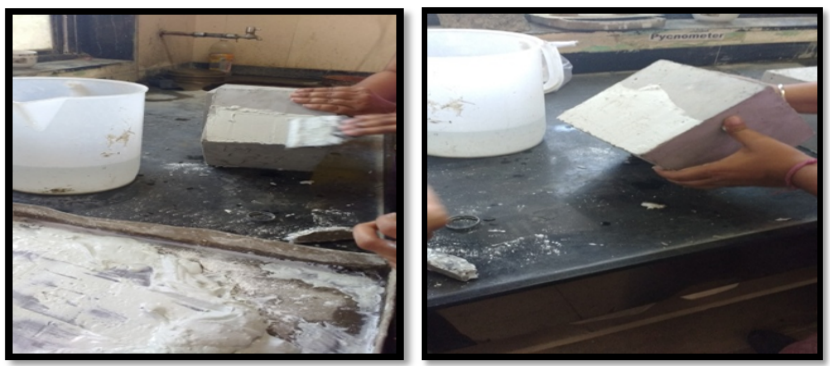

Coating of cubes by Dr. Fixit (bio concrete cubes)

\section{RESULT AND DISSCUSSION}

Table 1. Compressive strength

\begin{tabular}{|c|c|c|c|}
\hline $\begin{array}{c}\text { Compressive } \\
\text { Strength }\end{array}$ & $\begin{array}{c}\text { Conventional } \\
\text { conctere }\end{array}$ & $\begin{array}{c}\text { Bio } \\
\text { concrete }\end{array}$ & $\begin{array}{c}\% \\
\text { increase }\end{array}$ \\
\hline $3^{\text {rd }}$ day & 11.82 & 11.95 & 1.15 \\
\hline $7^{\text {th }}$ day & 17.15 & 17.67 & 3.05 \\
\hline $28^{\text {th }}$ day & 32.85 & 38.04 & 15.80 \\
\hline
\end{tabular}

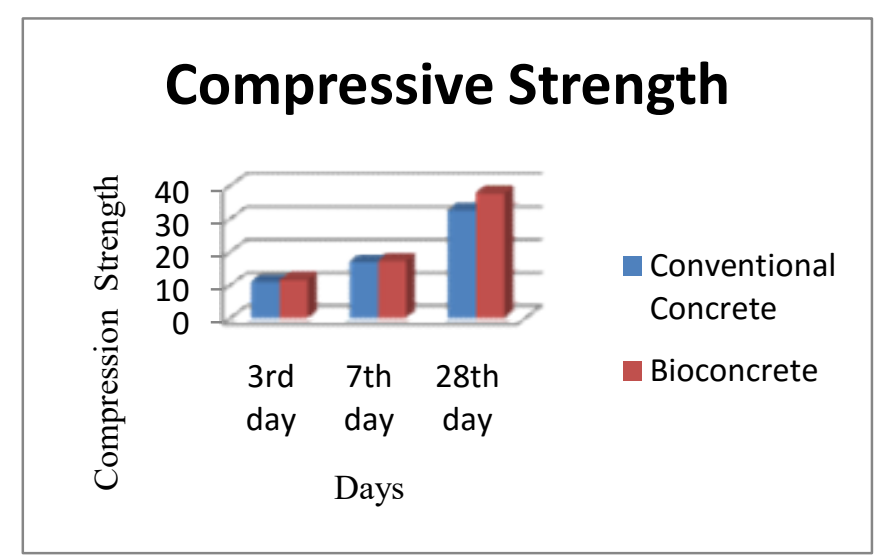

Graph 3: Compressive Strength

Table: Flexural Strength

\begin{tabular}{|c|c|c|c|}
\hline $\begin{array}{c}\text { Flexural } \\
\text { Strength }\end{array}$ & $\begin{array}{c}\text { Conventional } \\
\text { conctere }\end{array}$ & $\begin{array}{c}\text { Bio } \\
\text { concrete }\end{array}$ & $\%$ increase \\
\hline $28^{\text {th }}$ day & 3.55 & 3.73 & 5.18 \\
\hline
\end{tabular}

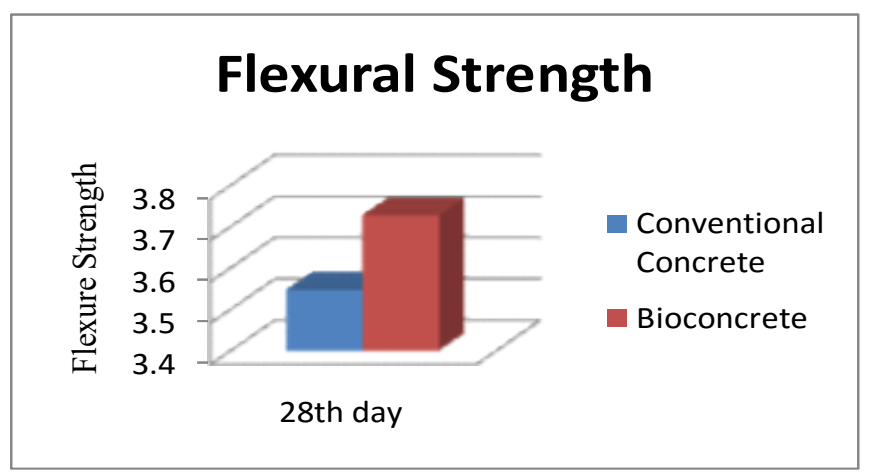

Graph 4: Flexural Strength
Table: Water Absorption

\begin{tabular}{|c|c|c|c|}
\hline $\begin{array}{c}\text { Water } \\
\text { Absorption }\end{array}$ & $\begin{array}{c}\text { Conventional } \\
\text { conctere }\end{array}$ & $\begin{array}{c}\text { Bio } \\
\text { concrete }\end{array}$ & $\begin{array}{c}\% \\
\text { decrease }\end{array}$ \\
\hline $28^{\text {th }}$ day & 3.17 & 1.965 & 3.83 \\
\hline
\end{tabular}

\section{Water Absorption}

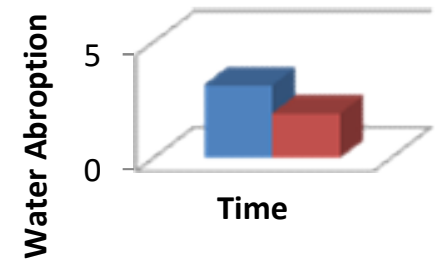

Conventional Concrete

Bioconcrete

Water Absorption

Sorptivity Test

\begin{tabular}{|c|c|c|c|}
\hline $\begin{array}{c}\text { Sorptivity } \\
\text { Test }\end{array}$ & $\begin{array}{c}\text { Conventional } \\
\text { conctere }\end{array}$ & $\begin{array}{c}\text { Bio } \\
\text { concrete }\end{array}$ & $\%$ decrease \\
\hline $28^{\text {th }}$ day & 4.01 & 2.29 & 6.89 \\
\hline
\end{tabular}

\section{Sorptivity}

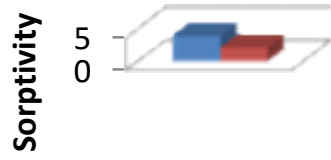

Time
Conventional Concrete

Bioconcrete
Fig -1 Sorptivity Test

Comparative Analysis Of Convensional Concrete (M25) and Bio Concrete :

The compressive strength test results reveals that there is increase in the strength for all the samples in which bacteria was incorporated as compared to specimen of the conventional concrete. There is significant increase of $1.15 \%, 3.05 \%, 15.08 \%$ was observed for cell concentration of $10^{10}$ cells per $\mathrm{ml}$ for 3,7 and 28 days respectively.

The flexural strength result was carried out after $28^{\text {th }}$ day. There is increase in strength of $5.18 \%$ for bioconcrete.

Water absorbtion test is performed after $28^{\text {th }}$ days of curing for oven dried specimen and results are plotted. Water absorbtion for bioconcrete specimen is less than conventional concrete specimen (M25). 


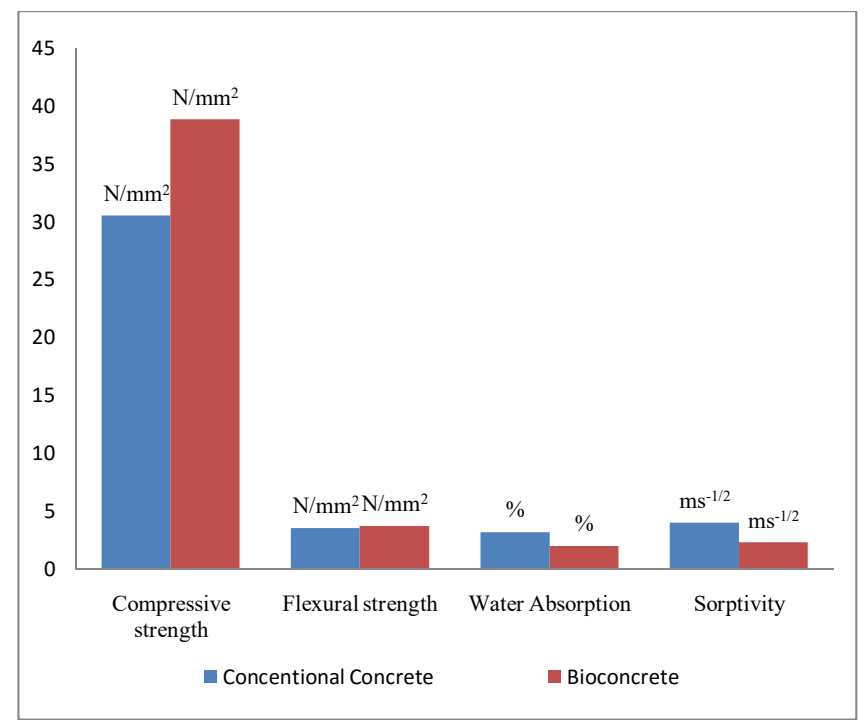

\section{CONCLUSIONS}

1. Thus we studied the percentage increase in compressive and flexural strength of bio concrete cubes compared to conventional cubes. From this project it is concluded that use of bacteria in concrete increases the percentage strength and reduces its water absoprtion and sorptivity.

2. Use of bacteria improves the compressive strength of concrete by filling the pores by calcite formation in fresh concrete. By using the bio concrete the compressive strength of concrete and durability of structure can be better than the conventional concrete. The impermeability of bio concrete will be increased than the conventional concrete.

3. Study of self healing process concluded that bacteria repairs the cracks in concrete by producing the calicum carbonates crystals which blocks the cracks and repairs it.

\section{REFERENCES}

[1] V. Ramakrishnan, R. K. Panchalan and S. S. Bang ; "Improvement of concrete durability by bacterial mineral precipitation "; Proceedings of 24th International Conference of Cement Microscopy, San Diego, California; Vol. 4234 (2001); 13-15 December 2000; pp. 168-176.

[2] P S Tan, M Q Zhang, D Bhattacharyya; "Processing and Performance of Self-Healing Materials"; IOP Conf. Series: Materials Science and Engineering 4 (2009) 012017; doi:10.1088/1757-899X/2009; 2009; pp 1-5 4/1/012017

[3] Kantha D. Arunachalam , K. S. Sathyanarayanan, B. S. Darshan, R. Balaji Raja; "Studies on the characterisation of Bio sealant properties of Bacillus sphaericus"; International Journal of Engineering Science and Technology; ISSN: 0975-5462; Vol. 2(3);2010; pp 270-277.

[4] A. Surendran and S. John Vennison; "Occurrence and Distribution of Mosquitocidal Bacillus sphaericus in Soil"; Academic journal of Entomology 4 (1); ISSN 1995-8994; 2011; pp 17-22.

[5] C. C. Gavimath, B. M. Mali, V. R. Hooli, J. D. Mallpur, A. B. Patil , D. P. Gaddi, C. R. Ternikar"; Potenial application of bacteria to improve the strength of cement concrete"; International Journal of Advanced Biotechnology and Research; Issue 1 ISSN 0976-2612; Vol 3; 2012; pp 541-544.

[6] Jagadeesha Kumar, R Prabhakara, PushpaH; "Effect of bacterial calcite precipitation on compressive strength of mortar cubes"; International Journal of Engineering and Advanced technology; ISSN: 2249-8958; Issue- 3; Vol 2; February 2013; pp: 486-491.

[7] Dr. Nele De Belie, Kim Van Tittelboom; "Self-Healing in Cementitious Materials- A Review"; International Journal of 3 R; Issue no. 10.3390/ma6062182; ISSN 1996-1944; 27 May 2013; pp 2182-2217.

[8] Mayur Shantilal Vekariya, Prof.Jayesh Kumar Pitroda; "Bacterial Concrete : New Era for construction industry"; International journal of engineering trends and technology (IJETT); Issue 9; Volume 4; September 2013.

[9] Keeratikan Piriyakul and Janjit Iamchaturapatr; "Biocementation through Microbial Calcium Carbonate Precipitation"; The Journal of Industrial Technology; Volume 9; Issue 3; September-December 2013; pp: 195218.

[10] Abhijitsingh Parmar, Ankit Patel, Vismay; "Effect of Depth of Crack on the Improvement of Compressive Strength of Concrete By Bacillus Pasturii"; International journal of engineering development and research; ISSN : 2321-9939; November 2013; pp: 62-65.

[11] V Senthilkumar,T Palanisamy, V N Vijayakumar; "Comparitive Studies on Strength Characteristic of Microbial Cement Mortars"; International Journal of ChemTech Research; Issue -1 Volume 6; Jan-March 2014; pp 578-590.

[12] Mohini P. Samudre, M. N. Mangulkar, S. D. Saptarshi; "A Review Of Emerging Way To Enhance The Durability and strength of concrete structures : Microbial concrete"; International journal of innovative research in science, Engineering and technology; Issue-2, Volume 3; Feb 2014; pp: 9311-9316.

[13] A. T. Manikandan, A. Padmavathi; "An Experimental Investigation on Improvement of Concrete Serviceability by using Bacterial Mineral Precipitation"; IJRSI; Issue III; Volume II; March 2015; pp: 46-49.

[14] Rajesh k. Verma, Leena Chaurasia, VishakhaBisht, Manisha Thakur; "Bio mineralization and bacterial carbonate precipitation in mortar and concrete"; American Institute of Science; Issue-3; Volume 2; March 2015; pp: 511.

[15] Sakina Najmuddin Saifee, Divya Maheshbhai, Jayesh Rameshbhai Juremalani; "International journal of research and development organisation, Critical appraisal on Bacterial Concrete"; International Journal of Research And Development Organisation; Issue3; Volume 2; March 2015; pp: 1-5.

[16] Salmabanu Luhar, SutharGourav; "A review paper on self healing concrete"; Journal of civil engineering research; 5(3); DOI: 10.5923/j.jce.20150503.01; 2015; pp: 53-58.

[17] Er. Satinder kaur; "Bacterial Concrete- A Concrete Solution for cracks-An Overview"; Issue 7; Volume 1; July 2015 
[18] H. M. Jonkers; "Bacteria-based self-healing concrete"; Microlab, Delft, the Netherlands HERON; Volume 56; 2011; pp: 1-2.

[19] Thirumalaichettiar; Percolation Modeling of SelfDamaging of Composite Materials; DOI: 10.1109/COMSWA ; 2015; pp. 1-5.

[20] Ellie Zolfagharifard ; "Biological concrete new era of self-healing civil structures"; ISBN 978-0-415-59316-8; 2015; pp- 840-847.

\section{REFERENCE BOOK}

1. A. M. NEVILLE- Properties of Concrete, Pearson Publications- Fourth edition.

2. SHETTY-Concrete technology, S Chand publication

\section{IS CODES}

1. IS 516-1959: Methods for test for Strength of Concrete

2. IS 10262- 1982 : Recommended guidelines for Concrete Mix Design.

\section{BIOGRAPHIES}

1. Harshali Jadhav, BE Student, Gokhale Education Society's R. H. Sapat College of Engineering, Nashik, Maharashtra, India.

E-mail: harshalijadhaw@gmail.com

2. Mitali Shelke, BE Student, Gokhale Education Society's R. H. Sapat College of Engineering, Nashik, Maharashtra, India.

E- mail: mitalishelke95@gmail.com

3. Neha Anwekar, BE Student, Gokhale Education Society's R. H. Sapat College of Engineering, Nashik , Maharashtra, India.

E-mail: anwekarneha@gmail.com

4. Pragati Bohare, BE Student, Gokhale Education Society's R. H. Sapat College of Engineering, Nashik , Maharashtra, India.

E-mail: pragatibohare@ymail.com 